\title{
The challenges and implementation in overcoming stunting by primary health care practitioners
}

\author{
Nurhannifah Rizky Tampubolon'1, Fitri Haryanti², Akhmadi Akhmadi² \\ 1 Program Studi D3 Keperawatan, Fakultas Farmasi dan Kesehatan, Institut Kesehatan Helvetia \\ 2 Magister Keperawatan, Fakultas Kedokteran Kesehatan Masyarakat Keperawatan, Universitas Gadjah Mada
}

\begin{tabular}{|c|c|}
\hline Article Info & Abstract \\
\hline $\begin{array}{l}\text { Article History: } \\
\text { Submitted: Dec } 21^{\text {st }}, 2020 \\
\text { Accepted: May } 21^{\text {st }}, 2021 \\
\text { Published: August } 31^{\text {st }}, 2021 \\
\text { Keywords: } \\
\text { Stunting; Primary health } \\
\text { care practitioner; The first } \\
1000 \text { days of life }\end{array}$ & $\begin{array}{l}\text { Stunting events in Indonesia have fallen by around } 7 \% \text { in the last } 5 \text { years. } \\
\text { That declined nationally has not been followed by a decrease in the } \\
\text { prevalence of stunting in all primary health care (PHC), one of the PHC in } \\
\text { Gunung Kidul Regency, has been able to reduce stunting prevalence in the } \\
\text { last } 3 \text { years. The purpose of this study was to find out how the challenges } \\
\text { and implementation faced by PHC practitioner Gunung Kidul Regency to } \\
\text { overcoming the problem of stunting. Qualitative descriptive with single } \\
\text { case study design. Data collection was conducted with semi-structured } \\
\text { interviews with } 5 \text { PHC practitioners and triangulation of resources with } \\
\text { cadres and village government. PHC practitioners village government and } \\
\text { cadres had the same perspective to overcoming the problem of stunting, } \\
\text { but the community was still unfamiliar. This was a challenge for health } \\
\text { center practitioner. In addition, the measurement of growth of children } \\
\text { under five carried out by cadres at the posyandu was considered to be } \\
\text { inaccurate health workers. Therefore the implementation of the } 1000 \text { HPK } \\
\text { Movement places more emphasis on strengthening the capacity of cadres in } \\
\text { capturing stunting toddlers and how cadres provide infant and child } \\
\text { feeding counseling so that stunting toddlers were more quickly detected } \\
\text { and stunting problems were more likely to be overcome. PHC practitioners } \\
\text { do the same perception with the village government and cadres in } \\
\text { overcoming the problem of stunting, so that the collaboration has an } \\
\text { impact on reducing the prevalence of stunting. The challenge faced by PHC } \\
\text { practitioners is to maintain the accuracy of the measurement of infant } \\
\text { growth by cadres in the posyandu by increasing assistance. }\end{array}$ \\
\hline
\end{tabular}

\section{PENDAHULUAN}

Kecukupan gizi merupakan salah satu hak anak untuk dapat tumbuh dan berkembang dengan optimal sesuai usia. Proses tumbuh dan berkembang akan mengalami perlambatan karena masalah kekurangan gizi, seperti stunting(1). Secara global
$22,2 \%$ atau sekitar 151 juta anak-anak usia kurang dari lima tahun mengalami stunting (2). Prevalensi stunting di Indonesia mengalami penurunan sekitar $7 \%$ dalam 5 tahun terakhir, yaitu dari 37,2\% (2013) menjadi $30,8 \% \quad$ (2018)(3). Persentase tersebut merupakan capaian penurunan stunting terbesar selama 10 tahun terakhir.

Corresponding author:

Nurhannifah Rizky Tampubolon

nurhannifahrizkytampubolon@helvetia.ac.id

Media Keperawatan Indonesia, Vol 4 No 3, August 2021

e-ISSN: 2615-1669

ISSN: 2722-2802

DOI: $10.26714 / \mathrm{mki} \cdot 4.3 .2021 .164-174$ 
Kabupaten Gunung Kidul merupakan kabupaten dengan prevalensi kejadian stunting tertinggi di Provinsi Daerah Istimewa Yogyakarta yaitu sebesar 20,60\%(4). Pada tahun 2014 prevalensi stunting lebih rendah yaitu $18,22 \%$ (5) dan pada tahun 2012 sebesar 23,67\% tetapi masih menjadi yang tertinggi dibandingkan dengan kabupaten lain(6).

Pemerintah Indonesia berkomitmen dalam menurunkan stunting dengan melakukan percepatan perbaikan gizi pada 1000 Hari Pertama Kehidupan (HPK)(7). Upaya tersebut dikenal dengan istilah Gerakan Nasional Sadar Gizi, disingkat menjadi Gerakan 1000 HPK yaitu selama 270 hari ( 9 bulan) masa kehamilan ibu ditambah 730 hari (usia 0-2 tahun) setelah anak lahir(8). Periode 1000 HPK merupakan periode kritis yang harus diselamatkan, kegagalan intervensi pada periode ini akan berdampak pada masa depan anak saat dewasa karena pada periode 1000 HPK berlangsung perkembangan otak yang sangat pesat(9). Proses perkembangan otak akan optimal jika didukung dengan asupan nutrisi yang berkualitas (10).

Penanggulangan masalah stunting menjadi tugas semua sektor melalui intervensi spesifik dan intervensi sensitif. Puskesmas sebagai penyelenggara upaya kesehatan masyarakat (UKM) menjadi suatu lembaga yang dapat menjalankan kedua intervensi penanggulangan masalah stunting (11). Puskesmas menjalankan intervensi spesifik melalui layanan di dalam gedung dan menjalankan posyandu 5 meja, sementara kegiatan puskesmas di luar gedung yang sifatnya bekerja sama lintas sektor seperti perumusan bersama dengan pemerintah desa terkait anggaran dana desa untuk sarana air bersih dan sanitasi merupakan bagian dari intervensi sensitif (12). Puskesmas memiliki peran penting dalam menginisiasi, memfasilitasi, dan mengawasi keberlanjutan program 1000 HPK di masyarakat melalui posyandu dan program lintas sektor dengan pemerintah desa(13).
Upaya mengatasi stunting sejalan dengan upaya perbaikan gizi pada program puskesmas, yang bentuk evaluasinya berupa cakupan pencapaian dalam persentase kuantitatif. Upaya dilakukan selama ini telah menunjukkan penurunan prevalensi secara nasional namun prevalensi stunting menurun belum terjadi di semua puskesmas. Salah satu puskesmas di Kabupaten Gunung Kidul yang memiliki kecenderungan prevalensi stunting menurun dalam 3 tahun terakhir adalah Puskesmas X, sementara puskesmas lain di kabupaten yang sama memiliki prevalensi stunting yang dinamis. Bagaimana tantangan dan implementasi dalam mengatasi masalah stunting oleh tenaga kesehatan puskesmas menjadi fokus penelitian ini.

\section{METODE}

Jenis penelitian ini adalah kualitatif deskriptif dengan rancangan studi kasus eksplanatoris. Penelitian ini dilakukan di Puskesmas X Kabupaten Gunung Kidul. Subjek penelitian menggunakan purposive sampling sebagai partisipan utama (P) yaitu berdasarkan penanggungjawab program yang berkaitan dengan pencegahan stunting, yaitu penanggungjawab bidang gizi, bidang Kesehatan Ibu dan Anak (KIA), bidang Promosi Kesehatan, dan bidang Kesehatan Lingkungan. Penelitian ini melibatkan Kepala Puskesmas selaku penanggungjawab umum untuk menggali informasi yang lebih komprehensif. Penelitian ini melibatkan partisipan pendukung (PP) untuk proses triangulasi sumber sebagai upaya menjaga keabsahan data yang berjumlah 13 orang.

Pengumpulan data dilakukan melalui wawancara semi terstruktur, diskusi kelompok terarah (DKT), observasi dan telaah dokumen. Wawancara semi terstruktur dilakukan untuk mengeksplorasi informasi pada semua partisipan, namun untuk partisipan pendukung dilakukan dengan DKT. 
Panduan eksplorasi informasi pada wawancara dan DKT telah disusun terlebih dahulu. Peneliti menggunakan alat perekam suara untuk merekam percakapan verbal dan menggunakan lembar catatan lapangan untuk mencatat respon non-verbal serta situasi yang berlangsung selama wawancara dan DKT. Observasi dilakukan ketika tenaga kesehatan puskesmas melakukan program pencegahan stunting. Telaah dokumen yang dilakukan yaitu mengintegrasikan hasil wawancara dengan dokumen yang tersedia. Pengumpulan data dilakukan sampai terdapat saturasi data yaitu dimulai dari Bulan Januari sampai Maret 2019. Selama pengumpulan data, peneliti dibantu seorang asisten penelitian.

Pengumpulan data penelitian dilaksanakan setelah mendapatkan persetujuan etik dari Komisi Etik Fakultas Kedokteran, Kesehatan Masyarakat, Keperawatan (FKKMK) Universitas Gadjah Mada dengan nomor surat KE/FK/1379/EC/2018. Peneliti memberikan lembar penjelasan dan lembar persetujuan (informed consent) pada setiap subjek penelitian. Lembar penjelasan memuat informasi terkait tujuan penelitian, manfaat penelitian, kerahasiaan data, dan kontak peneliti. Setelah subjek penelitian memahami keterlibatan sebagai partisipan penelitian, subjek dapat memilih untuk setuju atau tidak setuju menjadi partisipan penelitian dengan mengisi lembar informed consent.

Analisis data dilakukan menggunakan metode analisis Colaizzi (14). Peneliti melakukan transkrip verbatim pada hasil wawancara dan DKT. Hasil transkrip verbatim dibaca berulang kali untuk menentukan koding, dan menyusunnya menjadi kategori dan tema. Proses organisir data dan transkrip verbatim dilakukan dengan menggunakan software open code versi 4.03 .

\section{HASIL}

Hasil analisis tematik diperoleh 2 tema utama yaitu: 1) implementasi intervensi spesifik pencegahan stunting, dan 2) kendala dan tantangan pencegahan stunting oleh tenaga kesehatan puskesmas. Penjabaran kedua tema tersebut sebagai berikut:

\section{Tema 1: implementasi intervensi spesifik pencegahan stunting}

Tema pertama menggambarkan bagaimana perspektif dan implementasi upaya pencegahan stunting oleh tenaga kesehatan puskesmas melalui gerakan 1000 HPK. Implementasi yang digambarkan adalah bagaimana kerjasama antara tenaga kesehatan puskesmas, kader dan pemerintah desa serta bagaimana proses penjaringan dan sistem rujukan yang dilakukan pada bayi dengan masalah gizi, khususnya stunting.

\section{Perspektif tenaga kesehatan terkait stunting}

Tenaga kesehatan puskesmas memiliki perspektif bahwa stunting bukan masalah kecil karena berdampak pada masa depan anak dan sebagai masalah gizi yang bersifat kronis, perlu tindakan pencegahan dan penanganan yang berkelanjutan. Pencegahan stunting dinilai tidak cukup jika dilakukan hanya pada saat hamil atau pada 1000 HPK, tetapi perlu dilakukan sejak sebelum hamil yaitu mulai dari masa remaja.

"karena ini masalah bukan masalah kecil buat negara ya, masalah ada kaitannya nanti ee apa mempengaruhi kehidupan ke depannya anak atau bayi yang lahir stunting itu" (P1)

"kalau yang stunting itu kan sifatnya kronis ya, dalam artian kan tidak mungkin kalau cuma kita treatmentnya pada saat hamil terus bisa menurunkan, seperti itu. Jadi kita mulainya dari 
remaja. Kita ada posyandu remaja, kemudian kegiatan-kegiatan kita PKPR juga ada, sama kegiatan konseling remaja" (P3)

Tenaga kesehatan memiliki perspektif bahwa program-program pemerintah dalam mencegah stunting melalui intervensi spesifik pada 1000 HPK sudah tepat. Selain itu, program tersebut merupakan program rutin dari puskesmas. Upaya yang berbeda adalah adanya peningkatan penjaringan atau deteksi masalah gizi pada ibu hamil dan anak-anak balita. Tenaga kesehatan puskesmas merangkul kader dan pemerintah desa untuk bersama-sama lebih memperhatikan kelompok ibu hamil dan anak-anak balita. Tenaga kesehatan puskesmas memberikan pelatihan-pelatihan yang dapat meningkatkan kapasitas kader.

\section{Kerjasama puskesmas dengan pemerintah desa dan kader}

Tenaga kesehatan puskesmas memiliki pertemuan rutin berkala dengan kader dan pemerintah desa sebagai upaya kontrol atas intervensi spesifik 1000 HPK. Pertemuan rutin berkala yang dilakukan puskesmas dengan melibatkan kader dan pemerintah desa adalah pertemuan pada saat PTP (Perencanaan Tingkat Puskesmas), Lokakarya mini setiap tiga bulan dan PKP (Penilaian Kinerja Puskesmas). Pertemuan tersebut membahas masalah kesehatan yang dihadapi di desa-desa dalam lingkup kerja puskesmas dan upaya-upaya yang dapat dilakukan bersama untuk mengatasi masalah kesehatan yang ada.

Tenaga kesehatan puskesmas telah melakukan sosialisasi masalah stunting diberbagai kesempatan, seperti di pertemuan lintas sektor, pertemuan kader, pertemuan PKK dan di posyandu. Sosialisasi yang dilakukan di pertemuan lintas sektor diharapkan agar para tokoh masyarakat, terutama kader memahami masalah stunting dan membantu menyebarluaskan informasi tersebut ke masyarakat.

"kalau kita sudah me.. apa, udah menyarankan, udah penyuluhan, udah di tiap-tiap kita pertemuan udah, baik dari PKK, baik dari posyandu, khusus untuk pertemuan kader. itu sudah kita sampaikan. Demi untuk nanti tidak stunting terjadinya anak-anak kita yang akan datang" (P1)

"kita awalnya sampaikan ke kader. Kader kan juga pas pertemuan arisan, arisan keluarga, itu kan juga menyampaikan apa yang kita sampaikan. jadi itu hampir ya 50-60\% lebih masyarakat tahu dan paham bahwa stunting itu atau anak yang pendek itu bermasalah" (P5)

Tenaga kesehatan puskesmas menyadari peran kader sebagai ujung tombak puskesmas yang terlibat langsung pada kelompok sasaran program pencegahan stunting, sehingga memberikan pelatihan rutin secara berkala untuk meningkatkan dan menjaga kapasitas kader. Pelatihan yang diberikan yaitu pelatihan konseling PMBA (Pemberian Makan Bayi dan Anak) dan pelatihan pemantauan pertumbuhan. Pelatihan ini sebagai bekal kader dalam melaksanakan posyandu.

Praktik pemberian makan pada bayi atau baduta di wilayah kerja puskesmas masih ditemukan kesalahan yang dapat menyebabkan anak berisiko stunting. Bayi yang seharusnya mendapatkan ASI eksklusif terkendala karena diberikan teh atau makanan selain ASI, sementara untuk makanan pendamping ASI masih terlalu encer. Oleh karena itu tenaga kesehatan puskesmas merasa perlu dilakukan konseling PMBA.

Pengawasan atas pelaksanaan konseling PMBA oleh kader dilakukan dengan laporan di group whatsapp. Kader yang telah melakukan konseling mengirimkan foto atau video. Evaluasi lebih mendalam 
dilakukan melalui refreshing khusus kader PMBA. Petugas gizi melakukan evaluasi dengan menggali kendala yang dihadapi dan mengevaluasi bagaimana kader melakukan konseling pada kelompok sasaran. Pada saat evaluasi kelompok sasaran dibawa ke pertemuan kader dan petugas gizi untuk mendapatkan bagaimana PMBA yang dilakukan kader.

\section{Penjaringan masalah gizi}

Tenaga kesehatan puskesmas melakukan penjaringan dan perbaikan masalah gizi pada ibu hamil dan bayi yang berusia kurang dari 2 tahun di puskesmas melalui program-program rutin. Program rutin yang dilakukan antara lain yaitu peningkatan pengetahuan ibu hamil, pemeriksaan rutin selama hamil, perbaikan gizi dan rutin memantau tumbuh kembang anak. Tenaga kesehatan menilai bahwa pemeriksaan yang rutin dilakukan akan membantu tenaga kesehatan untuk mendeteksi sedini mungkin adanya kelainan. Semakin dini kelainan diatasi, semakin besar peluang masalah stunting teratasi.

Upaya meningkatkan pengetahuan ibu untuk mencegah terjadinya stunting dilakukan melalui kegiatan kelas ibu hamil, memanfaatkan media buku KIA saat konseling pemeriksaan kehamilan dan penyuluhan gizi di pertemuan-pertemuan masyarakat. Topik yang disampaikan dalam kegiatan kelas ibu hamil terkait kesehatan dan gizi ibu selama hamil sampai melahirkan, promosi IMD (inisiasi menyusui dini), manfaat ASI eksklusif, sampai persiapan persalinan dan perawatan nifas serta kontrasepsi. Ibu hamil sebagai kelompok sasaran dalam 270 hari pertama diharapkan mampu memenuhi gizi dan melakukan upayaupaya pencegahan stunting.

Tenaga kesehatan puskesmas melakukan penjaringan masalah gizi pada ibu hamil saat pemeriksaan kehamilan rutin. Permasalahan yang sering muncul adalah ketidakpatuhan ibu hamil mengonsumsi zat besi. Tenaga kesehatan puskesmas menggunakan strategi evaluasi dengan pertanyaan jebakan untuk mengevaluasi konsumsi zat besi ibu hamil sekaligus evaluasi pemahaman ibu terkait manfaat dan cara ibu mengonsumsi zat besi selama hamil.

"Biasanya kan kita, kita jaring. Sudah bisa cara minum obatnya, gimana caranya yang selama ini dilaksanakan, yang kayak gitu. Soalnya kalau kita ngomongnya, mba ini obate diminum, nanti diminum malem, jangan dibarengi ini jangan pake, kalau cuman seperti itu, kadang kala iya iya iya tapi iya iya thok, gitu loh. Tapi kalau misalnya dari hasil wawancara di awal, ternyata si ibu kok kayaknya belum paham tentang cara minum obat. Nah, itu kita berikan edukasi lagi" (P3)

Tenaga kesehatan memberikan edukasi kesehatan berdasarkan hasil evaluasi dan lebih menekankan untuk rutin mengonsumsi tablet zat besi dan menyampaikan dampak negatif yang ditimbulkan. Berdasarkan observasi yang dilakukan peneliti di layanan KIA saat ANC, tenaga kesehatan melakukan evaluasi konsumsi zat besi saat pengkajian dan atau saat terminasi. Edukasi pentingnya konsumsi tablet zat besi disampaikan tidak hanya pada saat data hasil pengkajian didapatkan, tetapi juga saat pemeriksaan kehamilan, dan saat meresepkan obat atau vitamin yang dibutuhkan ibu hamil. Tenaga kesehatan puskesmas lebih meningkatkan pengulangan edukasi pada ibu hamil yang tidak rutin mengonsumsi tablet zat besi dan yang memiliki kadar hemoglobin rendah. Bidan di layanan KIA memanfaatkan buku KIA sebagai media edukasi, dengan menunjukkan halaman buku KIA yang memuat jenis-jenis makanan sebagai sumber zat besi.

Penjaringan masalah gizi pada balita didapatkan dari hasil pemantauan pertumbuhan secara berkala. Hasil 
pengukuran pertumbuhan yang tidak normal akan dilaporkan langsung ke petugas gizi oleh kader koordinator. Petugas gizi melakukan kunjungan dan pengukuran ulang, jika didapatkan hasil pengukuran yang sama maka petugas gizi memberikan PMT (Pemberian Makanan Tambahan) sesuai kebutuhan. Program PMT berlangsung selama 3 bulan dengan pengukuran gizi berkala yang dilakukan langsung oleh tenaga kesehatan puskesmas bersama dengan kader.

Pada saat tenaga kesehatan melakukan kunjungan ke rumah balita yang dideteksi memiliki masalah gizi, petugas juga melakukan observasi terkait sanitasi sehingga penjaringan sanitasi dapat dilanjutkan oleh petugas kesehatan lingkungan puskesmas. Petugas kesehatan lingkungan puskesmas berkoordinasi dengan pemerintah desa untuk mengatasi masalah sanitasi. Petugas puskesmas dari layanan kesehatan lingkungan berperan dalam memberikan penyuluhan sanitasi sehat pada masyarakat di wilayah kerja puskesmas, sementara untuk pengadaan fasilitas dilakukan oleh pemerintah desa. Pemerintah desa melakukan penjaringan keluarga yang lebih diprioritaskan untuk mendapatkan jamban sehat. Proses penjaringan dan perbaikan sanitasi ini merupakan salah satu upaya koordinasi yang dilakukan oleh tenaga kesehatan puskesmas dengan pemerintah desa.

\section{Tema 2: kendala dan tantangan pencegahan stunting oleh tenaga kesehatan puskesmas}

Tema kedua terdiri dari dua kategori yaitu kendala tenaga kesehatan puskesmas dan tantangan upaya pencegahan stunting. Tema ini menjelaskan kendala yang dimiliki tenaga kesehatan puskesmas dalam memberikan pelayanan kesehatan dan tantangan yang dihadapi tenaga kesehatan puskesmas di masyarakat dalam mencegah masalah stunting.
Tenaga kesehatan puskesmas memiliki beberapa kendala yang berdampak pada optimalisasi upaya pencegahan stunting, yaitu beban tugas yang banyak, kurang koordinasi lintas program dan pemanfataan dana puskesmas. Berdasarkan jumlah dan kualifikasi sumber daya manusia yang tersedia di puskesmas, tenaga kesehatan yang ada sudah memenuhi standar peraturan menteri kesehatan. Kendalanya adalah tenaga kesehatan memiliki tanggungjawab dibeberapa program pelayanan dan dilimpahi tugas seperti administrasi manajemen puskesmas. Hal ini dianggap tenaga kesehatan puskesmas menjadi menyebabkan pelayanan menjadi kurang optimal.

Rangkap tugas seperti itu, dan itu nggak cuma saya yang ngalami. Semua petugas hampir mungkin 100\% di Gunung Kidul itu kayak gitu dan di kabupaten lain juga. Itu kan kelemahannya kita. Jadi tidak optimal. Kadang itu administrasi tercecer itu biasa, kadang misalnya diminta sekarang administrasinya kadang cuma ditulis itu.. artinya ada petugas sendiri kayak yang BOK itu nggak disampirkan, ada petugas sendiri. Harusnya seperti itu" (P2)

Pencapaian pelayanan kesehatan yang dinilai belum optimal oleh tenaga kesehatan puskesmas juga disebabkan karena koordinasi antar petugas masih kurang. Tenaga kesehatan dengan beberapa tanggungjawab program memiliki anggota tim yang juga menjadi penanggungjawab diprogram lain. Kurangnya kordinasi antar petugas dapat menyebabkan beberapa kegiatan lintas program menjadi terhambat pelaksanaannya. Kegiatan-kegiatan yang sudah direncanakan namun tidak berjalan menunjukkan bahwa puskesmas kurang mampu menyerap dana yang sudah dianggarkan.

\section{Kendala tenaga kesehatan puskesmas}

Nurhannifah Rizky Tampubolon / The challenges and implementation in overcoming stunting by primary health care practitioners 
Puskesmas telah memiliki dan menjalankan pertemuan khusus yang membahas rencana kegiatan selama 1 tahun ke depan. Pertemuan tersebut dijadwalkan di akhir tahun atau awal tahun, setelah laporan tahunan kinerja puskesmas dilakukan. Semua tenaga kesehatan puskesmas turut hadir karena kegiatan pelayanan saat itu ditiadakan. Kendalanya adalah, untuk perencanaan yang bersifat lebih teknis, yang dilakukan secara berkala tidak selalu dapat berjalan optimal. Hal ini dikarenakan tidak semua tenaga kesehatan puskesmas dapat hadir, karena sebagian sedang menjalankan kegiatan ke masyarakat.

\section{Tantangan upaya pencegahan stunting}

Tantangan pencegahan stunting yang dihadapi tenaga kesehatan puskesmas berasal dari kader dan masyarakat. Tantangan yang ditemui pada kader yang berdampak langsung pada optimalisasi upaya pencegahan stunting adalah belum semua kader memiliki keterampilan mengukur pertumbuhan balita secara akurat dan kemampuan memberikan konseling PMBA. Pelatihan peningkatan keterampilan kader di posyandu telah dilakukan oleh tenaga kesehatan puskesmas secara berkala, namun pelatihan tersebut diberikan pada perwakilan kader dari masing-masing posyandu. Artinya, belum seluruh kader mendapatkan pelatihan keterampilan sebagai kader posyandu.

Tenaga kesehatan puskesmas melakukan upaya pemantauan tumbuh kembang balita setiap 2 kali dalam setahun bersamaan dengan Pemantauan Status Gizi (PSG). Sementara, pemantauan pertumbuhan setiap bulan dilakukan oleh kader di posyandu. Tantangan yang dihadapi yaitu tenaga kesehatan menilai pengukuran pertumbuhan balita yang dilakukan oleh kader kurang akurat. Kekeliruan data pengukuran oleh kader disadari oleh tenaga kesehatan sehingga upaya peningkatan kapasitas kader terus dilakukan.

"Tapi kan data kadang ada yang diukur
oleh kader. Tapi itu sebenarnya udah
diajari pakai ini. Kalau untuk mengukur
panjang badan kan datar, tidak sambil
digendong. Ada yang sambil digendong
itu kan pernah sambil diukur. Itu kan
udah pelan-pelan kita rubahlah. Ada
pelatihan, pemantauan pertumbuhan
namanya. Itu kader kita latih dari
menimbang, dari pake puzzle itu, pake
puzzle itu kan urutan menimbang.
Habis itu praktik menimbang, praktik
mengukur tinggi badan dan itu
termasuk praktik mengisi KMS itu kan
juga penting, itujuga dilatih" (P2)

Berdasarkan hasil observasi di posyandu tanpa pendampingan tenaga kesehatan puskesmas, kader melakukan pengukuran tinggi badan anak dengan menggunakan pita meter, sementara di posyandu tersedia alat pengukur tinggi badan standar (microtoise). Posisi badan anak saat diukur tinggi badan dengan pita meter, tidak bersandar ke dinding, hal ini dilakukan karena anak menjadi rewel atau menangis saat diukur dengan microtoise. Pengukuran panjang badan pada bayi sama halnya dengan balita, menggunakan pita meter dan bayi dibaringkan di atas meja. Artinya kader masih membutuhkan pendampingan dan meningkatkan pemahaman pentingnya keakuratan pengukuran pada balita.

Tantangan yang ditemukan di masyarakat adalah masalah stunting belum familiar sehingga upaya pencegahan belum dapat berjalan optimal. Sosialisasi masalah stunting telah disampaikan ke masyarakat baik oleh tenaga kesehatan puskesmas maupun oleh kader, namun belum semua masyarakat menyadari stunting adalah masalah yang harus dicegah. Tenaga kesehatan memiliki perspektif bahwa masyarakat belum menyadari masalah stunting, terlebih pada anak usia di bawah 2 tahun. Hal ini terjadi karena pada saat bayi lahir, masyarakat belum menyadari 
adanya stunting dari panjang badan lahir bayi, sebagaimana masalah BBLR yang dapat dilihat dari berat badan lahir bayi.

"kalau masalah stunting itu belum. Belum familiar. Lah kita kan tahunya kan, apa namanya, kalau sudah gede (besar). Maksudnya kalau dia sudah lepas 2 tahun, baru mereka tahu. Loh iki bocah kok cebol (ini anak kenapa pendek). Nah biasanya kayak gitu. Tapi kadang mereka itu nggak ngeh (sadar). Lahir 47, jarang loh mbak. Biasanya itu kalau masyarakat itu nanya, oh nggih (iya) bu, lahir lanang (laki-laki), semene (segini) kilo, itu iya. Tapi kalau oh iya panjang badannya sekalian, itu nggak" (P3)

Pernyataan tenaga kesehatan yang menyebutkan bahwa masyarakat belum familiar dengan stunting didukung dengan pernyataan dari partisipan pendukung. Berdasarkan hasil wawancara dengan partisipan pendukung yaitu ibu hamil dan ibu dengan anak baduta tentang pemahaman stunting, 3 dari 4 partisipan pendukung menyatakan baru mendengar istilah stunting atau istilah balita pendek dan menyatakan tidak tahu masalah stunting.

Tantangan lain yang dihadapi tenaga kesehatan puskesmas di masyarakat yaitu kemampuan masyarakat dalam memenuhi kebutuhan gizi disadari belum seimbang oleh tenaga kesehatan puskesmas. Hal ini disebabkan akses untuk mendapatkan bahan pangan dan faktor ekonomi. Masyarakat lebih banyak mengonsumsi sayur, sementara untuk konsumsi buah dan ikan dinilai masih kurang. Kurangnya konsumsi ikan disebabkan karena di wilayah kerja puskesmas masyarakat sulit untuk menemukan ikan dan harga ikan dinilai mahal.

"Hanya budaya makan ikan disini belum ini loh belum bagus. Tapi ya disamping jauh dari pantai ya susah toh disini ya untuk mencari ikan itu. Ya saya kira itu sudah merupakan kalau ikan, ya mungkin dirasa jauh dari pantai, dari sungai, juga mungkin dari harga juga harga mahal" (P1)

Pernyataan tenaga kesehatan terkait pemenuhan gizi masyarakat yang belum seimbang juga didukung oleh pernyataan partisipan pendukung.

"Gizi seimbang ya, itu belum menjadi perhatian. Saya tidak menyimpulkan warga itu tidak mampu, tapi kadang nggak ngeh (sadar). Harus makan seimbang itu kayak apa nggak ngeh (sadar). Sing (yang) penting wareg (kenyang), yang penting makan. Nah ini kan budaya, sehingga kebutuhan untuk menghindari stunting belum sepenuhnya terjawab. Tetapi ada memang nggak mampu ya" (PP3)

"soalnya ada pernah itu, dapat info dari pasiennya bilangnya gini, lah kok ngombe (minum) obat terus nanti ndak dadi budeg (nanti apa tidak jadi tuli), soale jarene wes ngombe obat dadi budeg (soalnya katanya kalau minum obat terus jadi tuli). Nah, yang seperti itu. itu masih kita temukan mbak. Makanya kita kenapa harus terus-terusterus kita ulang-ulang" (P3)

Kondisi masyarakat yang juga menjadi perhatian tenaga kesehatan puskesmas yaitu masih adanya persepsi yang salah. Tenaga kesehatan telah mengenal sebagian masyarakat yang masih memiliki persepsi yang salah sehingga tindak lanjut yang diberikan yaitu meningkatkan edukasi dan melakukan penjaringan.

\section{PEMBAHASAN}

Tenaga kesehatan puskesmas, kader dan pemerintah desa telah memiliki perspektif yang sama terhadap masalah stunting dan upaya pencegahannya. Adanya perspektif yang sama berdampak positif pada implementasi upaya-upaya pencegahan 
stunting. Pemerintah desa dan kader menjadi lebih aktif dalam mengajak masyarakat untuk terlibat di posyandu. Keterlibatan aktif dari masyarakat ke posyandu mendukung upaya penjaringan status gizi pada balita walaupun masyarakat belum familiar dengan masalah stunting. Hal ini sejalan dengan salah satu penelitian yang menyebutkan bahwa ibu-ibu memiliki kepedulian terhadap pemantauan rutin terkait pertumbuhan dan perkembangan anak balitanya, namun masalah malnutrisi belum disadari sebagai masalah yang besar(15).

Berdasarkan standar pertumbuhan anak menurut WHO, anak dikatakan stunting apabila memiliki panjang badan atau tinggi badan dengan skor Z kurang dari -2 SD(2). Masalah stunting baru disadari setelah anak memiliki skor Z kurang dari -3SD atau sudah masuk ke dalam klasifikasi sangat pendek. Pertumbuhan anak tidak cukup diamati dengan memperhatikan tinggi badan anak-anak dengan teman seusianya untuk dapat menunjukkan ada atau tidak stunting, untuk mengetahuinya harus dilakukan pengukuran yang membandingkan hasil ukur dengan standar WHO. Pengukuran garis pertumbuhan membutuhkan ketekunan dan perhatian penuh agar hasil ukur akurat. Variabilitas hasil pengukuran dapat dipengaruhi oleh tempat dimana pengukuran dilakukan, perilaku anak yang kooperatif, alat ukur yang digunakan, teknik pengukuran dan metode menyimpan data(16). Memastikan kader mengukur pertumbuhan balita dengan akurat menjadi tantangan tenaga kesehatan puskesmas.

Pencegahan

stunting

yang diimplementasikan di Puskesmas X adalah dengan menjalankan upaya promotif melalui peningkatan edukasi terkait kesehatan dan gizi di masyarakat. Salah satu hasil penelitian menunjukkan bahwa pendidikan gizi melalui kelas ibu hamil dapat meningkatkan kepatuhan konsumsi tablet zat besi pada ibu hamil (15). Hasil penelitian lain menyebutkan bahwa jumlah paparan informasi terkait nutrisi dan kesehatan pada ibu, berkontribusi terhadap prevalensi masalah underweight dan stunting pada balita (17). Penelitian tersebut mendukung bahwa upaya peningkatan pengetahuan akan meningkatkan upaya pencegahan stunting dalam 1000 HPK yaitu ibu hamil yang patuh mengkonsumsi tablet zat besi.

Upaya promotif yang telah berjalan belum dapat menjangkau semua masyarakat, khususnya promosi terkait masalah stunting. Tenaga kesehatan puskesmas menyadari bahwa masalah stunting belum familiar di masyarakat. Pemahaman balita pendek yang samai d masyarakat masih terbatas pada keturunan, yaitu karena ibu atau orangtuanya pendek. Hal tersebut merupakan salah satu faktor risiko kejadian stunting (18). Namun, pemahaman tersebut belum cukup untuk dapat mencegah terjadinya kejadian stunting pada generasi berikutnya.

Pemanfaatan posyandu sebagai upaya promotif butuh diperkuat dari segi keterampilan kader. Peran kader sebagai pemberi informasi kesehatan di masyarakat, sebelumnya telah mendapatkan informasi yang komprehensif dari tenaga kesehatan puskesmas, akan tetapi bagaimana kader menyampaikan informasi ke masyarakat belum ada upaya monitoring dan evaluasi. Tenaga kesehatan puskesmas selain memberikan informasi dan pelatihan perlu melakukan pendampingan, sehingga upaya promotif yang dilakukan kader dapat berjalan efektif pada kelompok sasaran (12).

Kader di posyandu belum memanfaatkan adanya alat microtoise untuk mengukur tinggi badan anak dan masih tetap menggunakan pita meter. Kader mengetahui standar pengukuran tinggi badan balita menggunakan microtoise, namun karena balita sulit bersikap kooperatif saat pengukuran tinggi badan 
maka kader lebih memilih mengukur dengan pita meter. Keterampilan bagaimana pendekatan pada balita saat melakukan pengukuran pertumbuhan menjadi penting karena berpengaruh pada keakuratan hasil pengukuran. Pemanfaatan layanan posyandu menjadi tidak memberikan dampak pada kejadian stunting jika pengukuran panjang badan atau tinggi badan tidak dilakukan dengan benar karena gangguan pertumbuhan tidak terdeteksi sejak dini(19).

Tantangan dalam mengimplementasikan upaya pencegahan stunting yaitu terkait pemenuhan gizi yang belum seimbang. Masyarakat di wilayah kerja Puskesmas X lebih banyak mengonsumsi sayur-sayuran dan olahan kedelai seperti tahu dan tempe. Pemenuhan gizi belum seimbang tidak hanya disebabkan karena faktor ekonomi yang rendah, akses mendapatkan bahan pangan terbilang sulit. Pemenuhan gizi yang belum seimbang berkaitan dengan tidak terpenuhinya sebagian komponen gizi yang dibutuhkan tubuh. Komponen yang tidak dapat dipenuhi dari bahan makanan sayur-sayuran salah satunya adalah vitamin B12, yang dihasilkan dari makanan olahan hewani. Kekurangan vitamin B12 dapat menyebabkan gangguan hematologik (megaloblastik anemia) dan gangguan neurologik. Tanda-tanda gangguan hematologik bisa tidak terlihat pada kasus dengan tingkat folat yang tinggi (20).

Tahu dan tempe merupakan makanan yang dikonsumsi hampir setiap hari bersamaan dengan sayur-sayuran. Tahu dan tempe memiliki kandungan saturasi lemak dan kolesterol yang lebih rendah dibandingkan olahan daging, namun bukan sumber makanan yang baik untuk mendapatkan zat besi dan tidak mengandung vitamin B12. Kebutuhan vitamin B12 pada ibu hamil dapat terpenuhi walaupun konsumsi sayur lebih banyak, dengan tetap mengonsumsi olahan hewani setidaknya satu atau dua kali dan mendapatkan suplemen B12 dari layanan kesehatan. Penelitian menyebutkan bahwa ibu hamil yang vegetarian dapat menyebabkan janin mengalami kekurangan vitamin B12 sejak usia 2 bulan, sehingga dibutuhkan konsumsi ikan atau daging 1 atau 2 kali seminggu atau mengonsumsi suplemen vitamin B12 untuk memenuhi kebutuhan tubuh (21).

Upaya penanganan stunting merupakan prioritas pembangunan nasional yang tertuang dalam Rencana Aksi Nasional Gizi dan Ketahanan Pangan. Desa berperan untuk mendukung prioritas pembangunan nasional dengan menyusun kegiatankegiatanyang relevan dan berskala desa melalui APBDes (Anggaran Pendapatan Belanja desa)(22). Penanganan stunting menggunakan dana desa diperkuat dengan adanya Permendesa nomor 19 tahun 2017 tentang Prioritas Penggunaan Dana Desa. Prioritas penggunaan dana desa terkait stunting dimuat dalam Peraturan Menteri Desa, Bab III pasal 4, yang mana penggunaan dana untuk membiayai pembangunan desa dimuat pada pasal 5 dan pasal 7 untuk membiayai program dan kegiatan di bidang pemberdayaan masyarakat(23).

\section{SIMPULAN}

Berdasarkan hasil penelitian ini, didapatkan kesimpulan bahwa selama ini penyuluhan masalah stunting masih ditingkat tokoh-tokoh masyarakat belum menyentuh semua lapisan masyarakat. Tenaga kesehatan puskesmas menjalin komunikasi dan kerjasama yang baik dengan pemerintah desa dan kader melalui pertemuan rutin sehingga terbentuk persepsi yang sama dalam mengatasi masalah stunting. Masyarakat yang belum familiar dengan masalah stunting merupakan tantangan bagi tenaga kesehatan puskesmas untuk lebih meningkatkan pendampingan penyuluhan kesehatan yang dilakukan kader di posyandu. Penyuluhan pencegahan stunting diharapkan mencakup gizi seimbang dan pendampingan juga 
diperlukan pada kader saat melakukan pemantauan pertumbuhan balita untuk memastikan hasil pengukuran benar-benar akurat.

\section{UCAPAN TERIMAKASIH}

Terima kasih kepada seluruh partisipan yang telah bersedia meluangkan waktu untuk menjadi subjek penelitian ini.

\section{REFERENSI}

[1] Krishna A, Mejía-Guevara I, McGovern M, Aguayo V, Subramanian S V. Trends in inequalities in child stunting in South Asia. Matern Child Nutr [Internet]. 2017;(August):e12517. Available from: http://doi.wiley.com/10.1111/mcn.12517

[2] UNICEF/WHO/World Bank Group. Level and Trends in Child Malnutrition. Jt Child Malnutrition Estim 2018 Ed. 2018;1-16.

[3] Riskesdas. Hasil Utama Riskesdas 2018. Kementerian Kesehatan Badan Penelitian dan Pengembangan Kesehatan; 2018.

[4] Dinas Kesehatan Provinsi. Profil Kesehatan Provinsi Daerah Istimewa Yogyakarta. 2017.

[5] Peraturan Gubernur DIY. Peraturan Gubernur Daerah Istimewa Yogyakarta Nomor 80 Tahun 2016 Tentang Rencana Aksi Daerah Pangan dan Gizi. 2016.

[6] Dinas Kesehatan Provinsi. Profil Kesehatan Provinsi Daerah Istimewa Yogyakarta. 2016.

[7] Kementerian Kesehatan RI. Pendekatan Program Kesehatan Masyarakat Tahun 2018. 2017.

[8] Khoeroh H, Indriyani D. Evaluasi Penatalaksanaan Gizi Balita Stunting. Unnes J Public Heal. 2017;6(3):1-7.

[9] Fregonese F, Siekmans K, Kouanda S, Druetz T, Ly A, Diabaté S, et al. Impact of contaminated household environment on stunting in children aged 12-59 months in Burkina Faso. Vol. 71, Journal of Epidemiology and Community Health. 2017. p. 356-63.

[10] Trihono, Atmarita, Tjandrarini DH, Irawati A, Utami NH, Tejayanti T, et al. Pendek (Stunting) di Indonesia, Masalah dan Solusi. Sudomo M, editor. Lembaga Penerbit Balitbangkes. Jakarta: Lembaga Penerbit Balitbangkes; 2015. 218 p.

[11] Kementerian Kesehatan RI. Cegah Stunting itu Penting. 2nd ed. Jakarta: wartaKesmas; 2018.

[12] Bappenas. Penguatan pelayanan kesehatan dasar di puskesmas. Komariah L, Imani N, editors. Jakarta: Direktorat Gizi Masyarakat; 2018.

[13] Astuti S, Megawati G, CMS S. Gerakan pencegahan stunting melalui pemberdayaan masyarakat di Kecamatan Jatinangor Kabupaten Sumedang. J Apl Ipteks untuk Masy. 2018;7(3):185-8.

[14] Creswell JW. Research Design: Pendekatan Metode Kualitatif, Kuantitatif, dan Campuran. 4th ed. Pustaka Pelajar; 2017.

[15] Nurkharistna M, Jihad A, Rejeki S, Hartati E. Overview of experiences of pregnant women about the role of nurses as educators on healthy behaviours of the Era of Sustainable Development Goals pregnancy. Media Keperawatan Indones. 2020;(18).

[16] Campisi SC, Cherian AM, Bhutta ZA. World perspective on the epidemiology of stunting between 1990 and 2015. Horm Res Paediatr. 2017;88(1):70-8.

[17] Sahanggamu PD, Purnomosari L, Dillon D. Information exposure and growth monitoring favour child nutrition in rural Indonesia. 2017;26(February 2015):313-6.

[18] Alifariki LO, Rangki L, Haryati H, Rahmawati R, Sukurni S, Salma WO. Risk Factors of Stunting in Children Age 24-59 Months Old. Media Keperawatan Indones. 2020;3(18).

[19] Beal T, Tumilowicz A, Sutrisna A, Izwardy D, Neufeld LM. A review of child stunting determinants in Indonesia. Matern Child Nutr. 2018;(March):1-10.

[20] Davis JN, Brown H, Ramsay SA. Gaps in international nutrition and child feeding guidelines : a look at the nutrition and young child feeding education of Ghanaian nurses Public Health Nutrition. 2017;(May).

[21] Winckel M Van, Velde S Vande, Bruyne R De, Biervliet S Van. Clinical practice: Vegetarian infant and child nutrition. 2017;1489-94.

[22] Kementerian Desa Pembangunan Daerah Tertinggal dan Transmigrasi. Buku saku desa dalam penanganan stunting. 2017;2-13.

[23] Permen Desa. Peraturan Menteri Desa, Pembangunan Daerah Tertinggal, dan Transmigrasi republik Indonesia tentang Penetapan Prioritas Penggunaan Dana Desa Tahun 2018 [Internet]. Menteri Desa, Pembangunan Daerah Tertinggal, dan Transmigrasi Republik Indonesia Indonesia; 2017 p. 67. Available from: https://sooko.mojokertokab.go.id/upload/Per menDPDTT 19 Tahun 2017 Penetapan Prioritas DD Tahun 2018.pdf 